PERICA ŠPEHAR

Belgrade University, Faculty of Philosophy,

Department of Archaeology

11000 Belgrade, Serbia

perica.spehar@gmail.com
904:711.42”652/653”(497.11)

904:730”652/653”(497.11)

COBISS.SR-ID 212286988

Original research article

Received: December 26th 2013

Accepted: February 15th 2014

\title{
THE IMPERIAL STATUE FROM IUSTINIANA PRIMA ${ }^{1}$
}

\begin{abstract}
At the time of the renewal of the Byzantine Empire during the reign of the emperor Justinian I, a new city was built in Dacia Mediterranea as the imperial endowment - Iustiniana Prima. Today it is usually believed that the mentioned city, described by Procopius, can be identified with the archaeological site of Caričin grad.

During the research of the circular forum in the Upper Town, several fragments of the bronze statue were discovered. Based on the analysis of the analogous artistic parallels, it could be concluded that the fragments from Iustiniana Prima were the lower parts of the bronze muscle cuirass of the monumental imperial statue, about $2.2 \mathrm{~m}$ high. Its style and the place of its find, as well as the fact that the fragments were discovered on the site which has only the horizons of 6th and $7^{\text {th }}$ century, suggest with some certainty that it was the standing statue of Justinian I. The emperor was displayed on the circular forum of Iustiniana Prima, the center of the newly formed imperial town: according to the analogies, he had the globe with cross as the symbol of the worldly power in one hand, and the cross or more probably spear in another.
\end{abstract}

Keywords: Byzantine Empire, Justinian I, Iustiniana Prima, imperial statue.

The golden age of the early Byzantine Empire was the period of the rule of Justinian I (527565). It was marked by the re-conquering of the lost territories, especially the Apennine Peninsula as the heart of the former Roman Empire, as well as with the numerous grand scale building projects. Besides the churches and fortifications, which were either built new or restored, newly built cities mirroring the spirit of the "new epoch" also played an important role in the time of Justinian's rule (Zanini 2003). According to the Procopius testimony, one such city emperor built in the land of Dardanians and named it Iustiniana
Prima. Namely, Justinian was born in the village of Taurisium near the castelum of Bederiana. His first building project in his fatherland was to enclose the village of his birth with the rectangular fortification with towers on all four angles, calling it Tetrapirgion. After that, in its close vicinity, he built a magnificent city (De aedificiis IV 1 , 104,20-107,2), which was chosen to be the seat of the Archbishopric (Iust. Nov. XI).

The archaeological site of Caričin grad, situated on the high Plato oriented N-S, modern scholars mostly identify with Iustiniana Prima, the eponym city and the endowment of Justinian

${ }^{1}$ This paper came out as a result of the work on the project The Processes of the Urbanization and Development of the Medieval Society, supported by the Ministry of Education, Science and Technological Development of the Republic of Serbia. (No. 177021). 


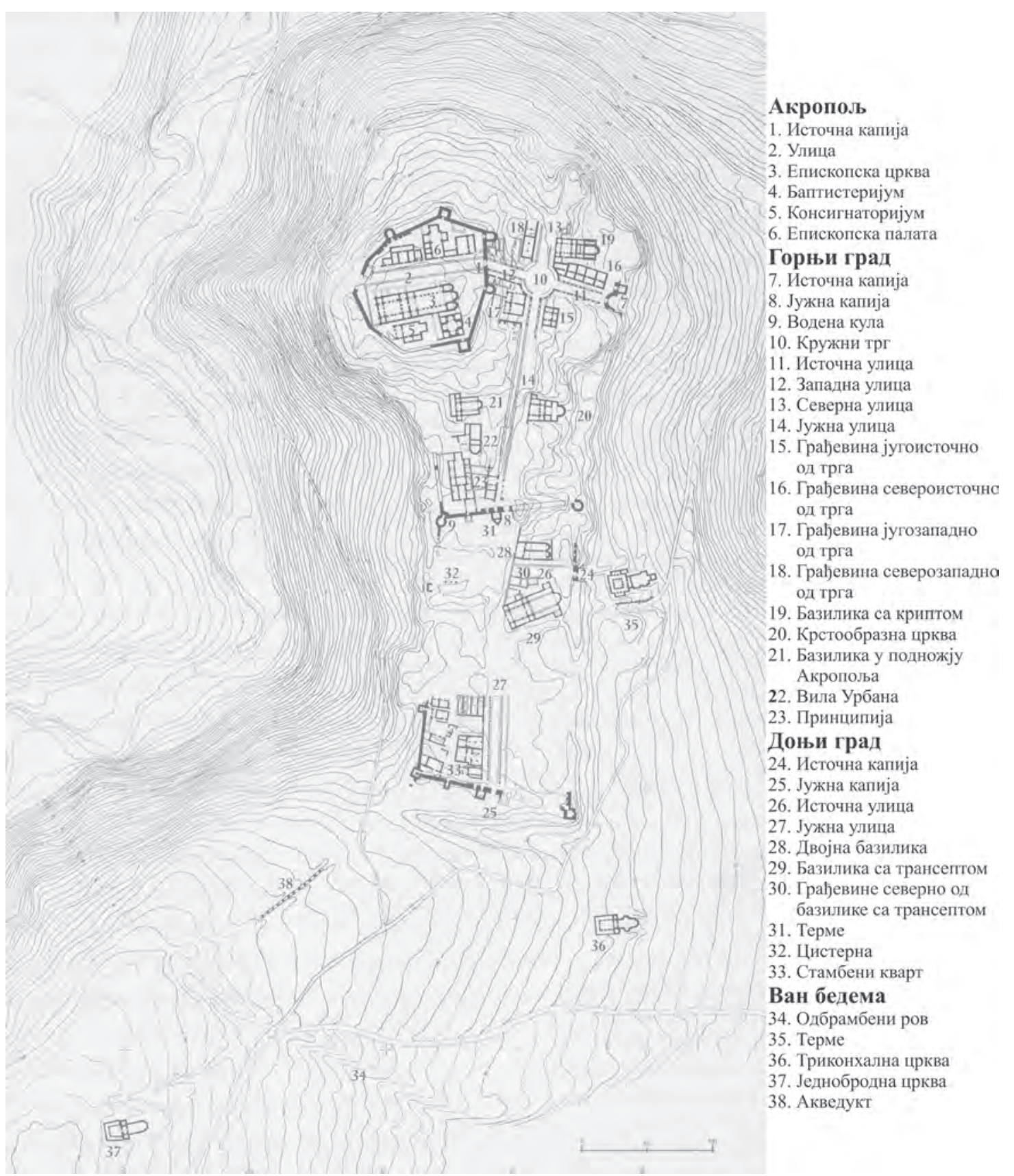

Fig. 1 Ground plan of Iustiniana Prima (after: Bavant and Ivanišević 2003, 13)

I. This early byzantine settlement formed between two small rivers, is situated $28.5 \mathrm{~km} \mathrm{SW}$ from Leskovac and $7 \mathrm{~km} \mathrm{~W}$ of Lebane, near the main road of the Morava-Vardar valley (Кондић and Поповић 1977, 7).

The research of this site was begun by Vladimir Petković as early as 1912. The size of the city of about 20 ha of the defended area, important architectural remains as well as the abundance of the small finds discovered there, resulted in the fact that the archaeological investigations on the site are still conducted today. For the last 30 years those campaigns have international character (Кондић and Поповић 1977, 8-13; Bavant and Ivanišević 2003, 14).

Based on up to date researches it was concluded that the city has three large defended areas: the Acropolis, the Upper- and the Lower Town (Fig. 1), while each rampart was aditionally strenghtened by the towers of different shape. 


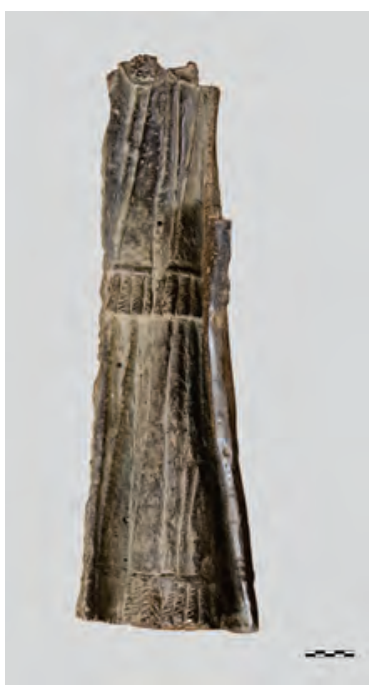

Fig. 2 Fragment of the bronze imperial statue (Documentation of the Archaeological Institute, Belgrade)

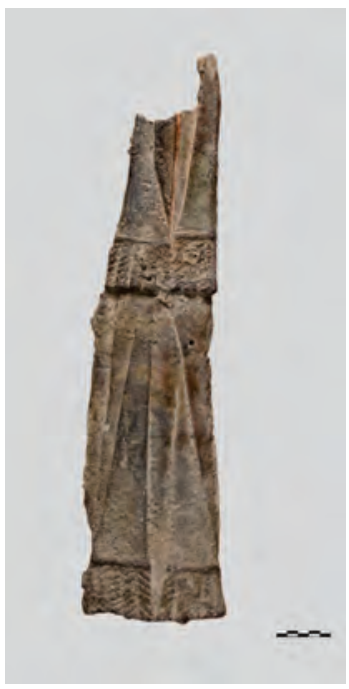

Fig. 3 Fragment of the bronze imperial statue (Documentation of the Archaeological Institute, Belgrade)

Besides, the remains of the aqueduct were found, as well as the dam, cistern, porticoed streets, principia, Episcopal palace, thermae, eight churches which significantly differed from each other and numerous profane buildings. Discovered architectural remains match the mentioned, although somewhat scarce description of the city of Iustiniana Prima written by Procopius (De aedificiis IV 1, 104,20-107,2), as well as the appearance of the cities built ex novo in the time of the Justinian`s reign. All the newly founded cities took from the antique heritage all the symbolical as well as real necessities as aqueduct, wide porticoed streets, baths, palaces... Yet, since they all were Christian cities the buildings meant for the amusement of Romans, such as theatres or hippodromes, were permanently abandoned in city planning. As another novelty, when compared with the ancient Roman city, churches appeared, since by that time (i.e. the $6^{\text {th }}$ century) Christianity had the crucial role in the social life of the Empire (Zanini 2003, 198-200).

In the crossing of two main streets of the Upper Town, a circular forum was discovered, which had $22 \mathrm{~m}$ in diameter, and with porticoes 3 $\mathrm{m}$ wide. It was situated at the top of the slope of the N-S street, which led from the main city gate in the south rampart of the Lower Town. The forum, which was indeed the early byzantine reminiscence to the Roman forum, was paved in stone.

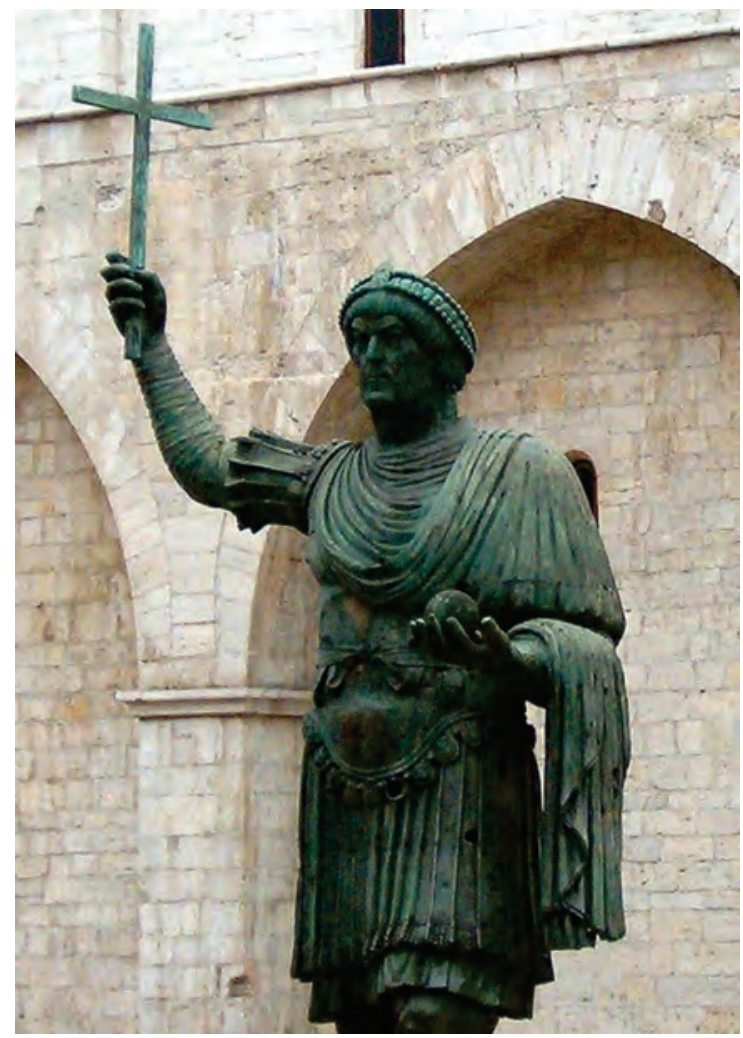

Fig. 4 Bronze monumental imperial statue from Barletta

In its middle stood the stone base of the column or of the statue, fragments of which were found on the site. According to the long lived tradition of Roman imperial cult, the statue of an emperor could found its place on the column as well, which will in the case of Iustiniana Prima mean that the statue of the emperor founder (i.e. Justinian) would find its place either directly on the base or on the top of the column, if it originally existed. He was presented as a standing figure in cuirass, which was also Roman iconographic model suggesting that the emperor was the commander of the army and the defender of the Empire (Grabar 1948, 57-59; Кондић and Поповић 1977, 51-54; Bavant and Ivanišević 2003, 22).

The imperial statue in Iustiniana Prima unfortunately wasn't preserved, except from several discovered fragments that were cut off from the monumental bronze image, of which only two were published. The first fragment has the dimensions of $58.2 \times 18 \mathrm{~cm}$ (Fig. 2), while the second has the dimensions of $50.5 \times 13.5 \mathrm{~cm}$ (Fig. 3). The longer one has the visible remains of two round endings, one of them shaped as a human mask with the beard, while on the right side it has a long drape 
which runs the entire length of the fragment. Other drapings, which are narrower, are covered with the bordures with fringes, one of which is in the middle and the other in the lower part of the preserved fragments of the statue. Those fragments belonged to the lower part of the cuirass, since the round endings are in fact agrafe with which pteruges (i.e. the rounded belt strips) were fastened, while the long draping on the left side was the part of the paludamentum, which was originally banded over

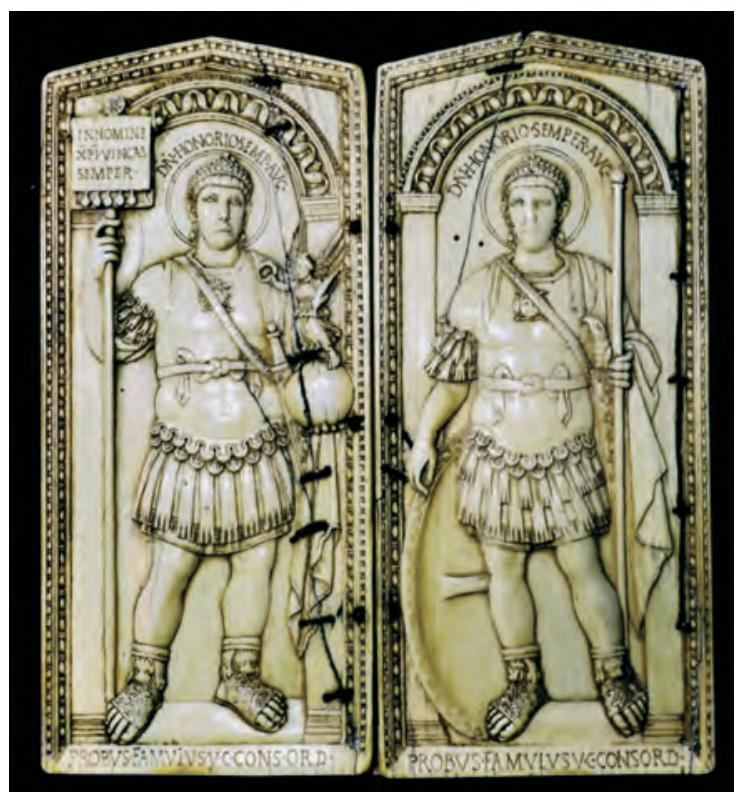

Fig. 5 Consular ivory diptych of Anicius Petronius Probus

the emperor's left arm. The lower sections of both fragments were the part of tunic (chlamida), worn under the cuirass.

According to the everything mentioned, it seems more than obvious that discovered fragments are the lower parts of the muscle cuirass made of bronze, so it was possible to determine that the entire statue without its base was circa $2.2 \mathrm{~m}$ high (Grabar 1948, 58, fig. 1; Кондић, Поповић 1977, 187, Cat. No. 1; Bavant and Ivanišević 2003, 60-61, Cat. Nos. 3-4; Баван and Иванишевић 2006, 93-94, Cat. No. 2; Byzanz 2010, 238, Cat. No. 182).

Emperor`s muscle cuirass, which was supposed to be originally integral part of the imperial statue in Iustiniana Prima, imitates the torso. Leather belts (pteruges), which were fastened to the cuirass, were protecting the shoulders, lower part of abdomen as well as the thighs. The cuirass is Hellenistic in origin, but came to use in
Rome quite early, primarily by the infantry and the cavalry, although it was also worn by the navy. During the Hellenistic age pteruges were positioned high on the belt, while in the case of the Roman cuirass they were placed on hips. Besides, there is certain differences in the appearance of the leather belts, which became narrower and longer in the time of the Roman domination. According to some scholars, pteruges were worn predominantly by special units, high officers and

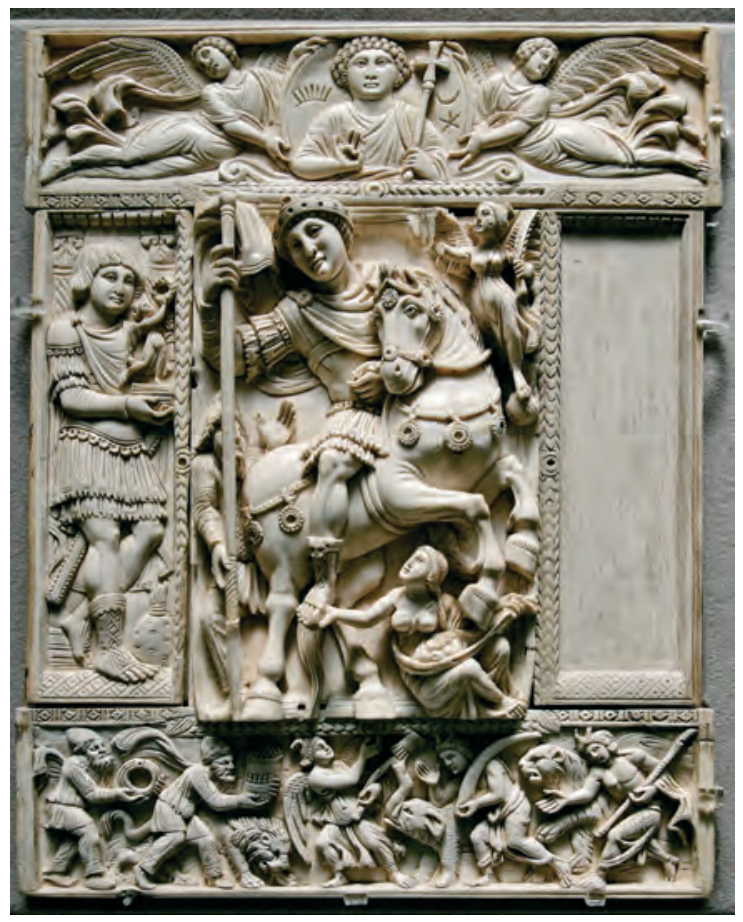

Fig. 6 Ivory diptych from Barberini collection

emperors, so in due time this kind of armor became the symbol of Roman power and imperium (Russell Robinson 1975, 147-149).

To this testify also the different Roman coinages, on which the emperor is represented as a horseman, dressed in muscle cuirass with chlamida underneath. The similar representation can be seen on the obverse of the medallion of Justinian I, now in the Bibliothèque Nationale de France in Paris (Age of Spirituality 1979, 4546, Cat. No. 44).

Chronologically and stylistically, the closest parallel to the find from Iustiniana Prima is almost completely preserved bronze imperial statue which stands today in front of the Church of the Holy Grave in Barletta, Italy. It was part of the war plunder taken after the fall of Constantinople in 1204. The ship on which this valuable cargo 
was transported suffered the destruction during its sail. The statue was preserved only by luck, since the sea cast it up on shore in 1309. Mentioned statue is the standing image of an emperor, $3.55 \mathrm{~m}$ tall, which together with its base has the height of $5.1 \mathrm{~m}$ (Fig. 4). It represents a middle-aged man wearing simple muscle cuirass with pteruges, below which is a tunic. His left leg is slightly spread outward, while in his stretched right arm he holds the cross. The lower part of the paludamentum is switched over his left arm, which is also stretched forward and carries the globe. The emperor wears military boots, and he has a diadem on his head. Based on the technology of its production, as well as on the stylistic characteristics, the statue was supposed to might have represented any emperor from Valentinian I (364-375) to Heraclius (610641), although it is most usually assumed that it indeed was Marcian (450-457) and that it originally stood on the column erected in Constantinople in the middle of the $5^{\text {th }}$ century (Johnson 1925; Grabar 1936, 16-17; Gerke 1973, 52; Age of spirituality 1979, 27-28, Cat. No. 23; Elsner 1998, 75, 77, Fig. 48).

Beside this example, there are others that testify about the usual way of representing an emperor during the longer period from the $4^{\text {th }}$ to the $6^{\text {th }}$ century. On the very beginning of the mentioned period is the marble statue of the emperor Constantine I (305-337), the remains of which stand today in front of the Palazzo dei Conservatori in Rome. Similar cuirass can be observed on the so called „Group of tetrarchs“, originally also from Constantinople, which are situated today in front of the Church of st. Marco in Venice. On the dyptich of Anicius Petronius Probus, roman consul in 406, an image of young emperor Honorius appeares (395-423), dressed in the same manner (Fig. 5). The uncertain emperor, Anastasius (491517) or Justinian I, is portrayed together with some general on the equestrian diptych from the Barberini collection (Fig. 6), which is kept today in Louvre. Both of the portrayed figures are also dressed in the muscle cuirass. Besides, one should mention the throne of Archbishop Maximian from Ravenna, dated to the middle of the $6^{\text {th }}$ century, on which the same cuirass is represented in the scenes from the Story of Joseph (Grabar 1948, 59; Elsner 1998, 84, Fig. 55; Byzanz 2010, 331, Kat. No. 444).

Since on the fragments of the imperial bronze statue from Iustiniana Prima the representations of the circular agrafe are preserved, it could be concluded that the cuirass was not the part of the early imperial portrait $\left(1^{\text {st }}-3^{\text {rd }}\right.$ century), when oval agrafe dominated. The most similar are the agrafe from the statue of Marcian from Barletta, as well as those on the Barberini diptych. On the equestrian statue of Justinian I from Constantinople, now lost but known according to the $16^{\text {th }}$ century drawing, same agrafe could be observed. Likewise, the position of the leather belts in the lower part, which are bended in the case of the equestrian statue, suggest that the statue from Iustiniana Prima was most certainly standing. Additional data about the chronological determination of the statue can also be obtained by the analysis of the shape of the belts as well as by their position, since the belts are fastened in two rows separate from each other. This way of fastening a belt is not known in early centuries of the Roman Empire, but it can be seen on the Barberini diptych as well as on the Throne of Archbishop Maximian from Ravenna. According to all the analogies mentioned above, the imperial statue from Iustiniana Prima can with great certainty be chronologically atributed to the $6^{\text {th }}$ century (Grabar 1948, 59-61; Age of spirituality 1979, 60, Fig. 7; Mango 1992).

Fragmentary state of its preservation enables only the limited possibilities for the determination of its original appearance. Still, A. Grabar proved with arguments more than 60 years ago that it indeed was an imperial statue (Grabar 1948). Based on the fact that it originates from the site where only horizon of the $6^{\text {th }}-$ early $7^{\text {th }}$ century could be found, as well as on the archaeological context, the statue could be atributed to Justinian I. Beside all the mentioned analogies, to this testify also the place where it was found, i.e. next to the town`s main square of circular shape, which was the successor of the ancient roman forum where an imperial statues were placed.

The ruler cult started in Rome from the time of Julius Cesar (100-44 BC), when the almost divine merits were ascribed to one person, characteristic above all for Jupiter as the supreme divinity (Baldwin Smith 1956, 22, 25; Fears 1981, 13, 45; Gradel 2005, 33-35). Erecting imperial statues was just one of the many ways in which imperial cult was demonstrated throughout the Empire. When Christianity became the state religion, the imperial cult disappeared although some prerogatives of the roman imperial titles remain, such as the title of Pon- 
tifex maximus which was used until Theodosius I. Christian emperor owes his imperium only to one God, in whose name he rules and fights the unbelievers (Шене и Флизен 2010, 16-17).

The acceptance of Christianity led to the abandonment of the imperial cult, but in reality the worship of the emperor still continued, although somewhat modified by the dogmatic interpretation of the Constantine`s contemporary and biographer Eusebius from Caesarea. According to him, the emperor is God`s vicar on Earth. Emperor was no longer the living god but was still preordained and had some godlike attributes. His most important role was to further enlarge the Christian Empire and to protect his Christian subordinates (Evans 1996, 58-62). As such, the emperor was most probably represented on the circular forum of Iustiniana Prima, which once dominated the newly founded city as the emperor`s endowment: according to the analogies, he could have globe with cross as the symbol of worldly domination in one hand, and cross or more likely a spear in the other.

The rule of Justinian I was the last successful attempt of renovatio imperii, and the emperor himself is still by some scholars consider as the last truly roman emperor. Unfortunately, as well as almost all of the monumental statues of his predecessor, the Justinian`s statue in Iustiniana Prima survived some kind of damnatio memoriae, although possibly not intentionally, since it was cut into pieces which were most probably later re-melted.

\section{HISTORICAL SOURCES}

\section{De aedificiis}

Procopii de aedificis, ed. J. Haury, Lipsiae 1913.

Ius. Nov.

Iustiniani Novellae, y: Гръцки извори за бъгарската история II, ур. И. Дуйчев и др., София 1958, 39-86.

\section{BIBLIOGRAPHY}

Age of Spirituality 1979

Age of Spirituality. Late Antique and Early Christian Art, Third to Seventh Century, ed. K. Weitzman, New York: The Metropolitan Museum of Art.

Baldwin Smith, E. 1956

Architectural Symbolism of Imperial Rome and the Middle Ages, Princeton: Princeton University Press.

Bavant, B. and Ivanišević, V. 2003

Iustiniana Prima - Caričin grad, Beograd: Francuski kulturni centar, Arheološki institut.

Баван, Б. и Иванишевић, Б. 2006

Iustiniana Prima - Царичин град, Лесковац: Народни музеј.

\section{Byzanz 2010}

Byzanz. Pracht und Altag, Bohn: Hirmer, Römisch-Germanisches Zentralmuseum.

\section{Elsner, J. 1998}

Imperial Rome and the Christian Triumph, Oxford-New York: Oxford University Press.

\section{Evans, J.A.S. 1996}

The Age of Justinian. The circumstances of imperial power, New York: Routledge.

Fears, J.R. 1981

The cult of Jupiter and Roman Imperial Ideology, Aufstieg und Niedergang der römischen Welt 2/17/I, 3-141.

\section{Gerke, F. 1973}

Kasna antika i rano hrišćanstvo, Novi Sad: Bratstvo i Jedinstvo.

Grabar, A. 1936

L`empereur dans l'art byzantine, Paris: Les Belles Letters.

Grabar, A. 1948

Les Monuments de Tsaritchin Grad et Iustiniana Prima, Cahiers Archéologiques III: 49-63. 
Gradel, I. 2005

Emperor Worship and Roman Religion, Oxford: Oxford University Press.

\section{Johnson, F.P. 1925}

The Colossus of Barletta, American Journal of Archaeology 29/1: 20-25.

Кондић, В. и Поповић, В. 1977

Царичин град. Утврђено насеље у византијском илирику, Београд: САНУ.

Mango, C. 1992

The Columns of Justinian and his Successors. Studies of Constantinople. Collected studies series CS394, Aldershoot/Brookield: Variorum: 1-20.

\section{Russell Robinson, H. 1975}

The armour of imperial Rome, London: Arms and Armour Press.

\section{Шене, Ж-К. и Флизен, Б. 2010}

Византија. Историја и иивилизащија, Београд: Clio.

\section{Zanini, E. 2003}

The Urban Ideal and Urban Planning in Byzantine New Cities of the Sixth Century A.D., in: Theory and Practice in Late Antique Archaeology, Late Antique archaeology 1, (eds.) L. Lavan, W. Bowden, Leiden-Boston: Brill: 196-223.

\section{REZIME}

\section{CARSKA STATUA IZ PRVE JUSTINIJANE}

Ključne reči: Vizantijsko carstvo, Justinijan I, Prva Justinijana, carska statua.

Tokom poslednje velike obnove Rimskog carstva u vreme Justinijana I, na prostoru provincije Sredozemne Dakije novi grad, Prva Justinijana, osnovan je kao carska zadužbina. Danas je uglavnom prihvaćeno da se ovaj grad, poznat iz Prokopijevih opisa, može identifikovati sa naseljem otkrivenim na arheološkom lokalitetu Caričin grad, koji se arheološki istražuje već više od jednog veka. Prilikom iskopavanja kružnog trga u
Gornjem gradu, otkriveno je nekoliko fragmenata bronzane statue, koji predstavljaju donje delove muskulatornog oklopa. Pomenuti fragmenti predstavljaju donji deo oklopa, budući da su kružni završeci u njihovom gornjem delu kopče kojima se vezuju pterige, tj. kružni kožni kaiševi, dok dugi nabori sa leve strane predstavljaju delove ogrtača prebačenog preko leve ruke statue. U donjim delovima oba fragmenta predstavljena je tunika (chlamida), koja se nosila ispod oklopa.

$\mathrm{Na}$ osnovu analize sličnih umetničkih dela, može se zaključiti da su fragmenti iz Prve Justinijane bili deo monumentalne carske stojeće statue, visoke oko 2,2 m. Stilske karakteristike otkrivenih fragmenata, mesto njihovog nalaza, kao i činjenica da potiču sa nalazišta koje ima samo horizont 6 - početka 7. veka, ukazuju sa velikom sigurnošću da je reč o statui Justinijana I. Kult rimskog vladara, koji se između ostalog manifestovao i kroz podizanje carskih statua, započeo je od vremena Julija Cezara. Kada je hrišćanstvo proglašeno za državnu religiju, dogodile su se značajne promene, iako su carevi sve do Teodosija I zadržali neke od važnih titula rimskih careva npr. titulu pontifex maximus.

Iako je prihvatanje hrišćanstva rezultiralo ukidanjem carskog kulta, posebne počasti su, premda modifikovane, i dalje ukazivane vladarima. Mada car više nije smatran bogom, bio je božanski predodređen i imao je božanske odlike, iako je njegova nova uloga bila da širi hrišćasko Carstvo i da zaštiti njegove podanike. Kao takav, car je prikazan i na kružnom trgu u Prvoj Justinijani, središtu novoosnovanog carskog grada. Sudeći prema analogijama, imao je globus sa krstom kao simbolom svetske vlasti u jednoj ruci i krst ili verovatnije koplje u drugoj. 